\title{
Cumhuriyet'in IIlk Yıllarında Yurttaşlık Eğitimi: Cumhuriyet Çocuklarına Malûmât-ı Vataniye Ders Kitabı Örneği
}

Civic Education in the First Years of the Republic: Cumhuriyet Çocuklarına

Malumat-ı Vataniye Textbook Example

\section{Seval YINILMEZ AKAGÜNDÜZ}

Kırşehir Ahi Evran Üniversitesi, Fen-Edebiyat Fakültesi, Felsefe Bölümü, sevalyinilmez@gmail.com orcid.org/0000-0003-4200-352X

\section{Article Info}

\begin{tabular}{|c|c|}
\hline Article Type & Research \& Theoretical \\
\hline Received & 01.12 .2019 \\
\hline Accepted & 08.03 .2020 \\
\hline DOI & $10.17497 /$ tuhed.653698 \\
\hline Corresponding & Seval YİNILMEZ AKAGÜNDÜZ \\
\hline $\begin{array}{l}\text { Autnor } \\
\text { Cite }\end{array}$ & $\begin{array}{l}\text { Yinilmez Akagündüz, S. (2020). Cumhuriyet'in ilk yıllarında yurttaşlık } \\
\text { eğitimi: Cumhuriyet çocuklarına malûmât-1 vataniye ders kitab1 örneği. } \\
\text { Turkish History Education Journal, 9(1), ss. 109-131. DOI: } 10.17497 / \\
\text { tuhed.653698 }\end{array}$ \\
\hline
\end{tabular}


Öz: Çalışmada Cumhuriyet'in ilk yıllarında ulus-devlet bilincinden hareketle ilk mekteplerde toplumsal değerler ve ahlak eğitimi konusunda öğrencileri bilgilendirmek amacıyla hazırlanan "Cumhuriyet Çocuklarına Malûmât-ı Vataniye" adlı eser incelenmiştir. Illk mekteplerde okutulmak üzere hazırlanan bu eser "Malûmât-ı Medeniye" derslerine yardımcı bir ders kitabı olarak toplumsal değerler ve ahlak eğitimi konularında bilgi vermektedir. Cumhuriyet Çocuklarına "Malûmât-ı Vataniye"de yer alan metinlerden hareketle Cumhuriyet'in ilk yıllarında ilköğretimde iyi yurttaş yetiştirilebilmek için verilmesi amaçlanan değerler, ahlak eğitimin boyutlarıyla analiz edilmiştir. "Cumhuriyet Çocuklarına Malûmât-ı Vataniye" adlı çalışmanın incelenmesinde doküman analizi yaklaşımı kullanılmıştır. Örneklem alınmamış, eserin tamamı içerik analizi yöntemiyle incelenmiştir. "Bireysel Gelişim" ve "Toplumsal Uyum" kategorileri ve alt temalarından hareketle incelenen eserde frekans ve yüzde değerlerinin hesaplanması sonucunda "toplumsal uyum" kategorisine eserde daha fazla yer verildiği tespit edilmiştir. "Bireysel Gelişim" kategorisi \%19 ve "Toplumsal Uyum" kategorisi de \%81 oranlarında yer kaplamaktadır. Eserde bazı bölümlerden sonra "Hülasa: Öğrenilecek Noktalar ve Sualler" başlıklarına yer verilirken, bazılarından sonra da "Güzel Sözler" başlığıyla atasözü ve deyimlere yer verildiği görülmektedir. Öte yandan, kitapta nasihat ya da öğüt vermenin öğrenim yaklaşımı olarak kullanıldığı da anlaşıımaktadır.

Anahtar Kelimeler: Cumhuriyet Dönemi, Yurttaşlık Eğitimi, Ahlak Eğitimi, Değer, Cumhuriyet Çocuklarına Malûmât-ı Vataniye Ders Kitabı

\begin{abstract}
In this study, the work titled "Cumhuriyet Çocuklarına Malûmât-ı Vataniye" prepared for primary schools in the first years of the Republic with the aim of informing students on social values and moral education based on the sense of nation-state was examined. This work, which was prepared to be taught in primary schools, gives information on the subjects of social values and moral education as a supplementary textbook for "Malumat-ı Medeniye" classes. The values intended to be taught in primary schools based on the texts in "Cumhuriyet Çocuklarına Malûmât-ı Vataniye" in the first years of the Republic were evaluated with the dimensions of compatriot edification and moral education and the prominent values in compatriot edification were revealed. Document analysis was used in the examination of the work titled "Cumhuriyet Çocuklarına Malûmât-ı Vataniye". No sampling was performed and the entire work was examined using the content analysis method. In the work that was examined based on the "Personal Development" and "Social Integration" categories and subthemes, it was determined as a result of the calculation of frequency and percentage values that the category "Social Integration" was more frequently included. The personal development category occupied $19 \%$ of the work while the social integration category occupied $81 \%$. It was found after some estimations that the title "Summary: Topics to learn and questions" was included in the work while idioms and proverbs were given under the title "Words of Wisdom". On the other hand, it is understood that advice-giving was used in the work as an educational approach.
\end{abstract}

Keywords: Republican Period, Civic Education, Moral Education, Value, Cumhuriyet Çocuklarına Malûmât-ı Vataniye Textbook 


\section{Extended Summary}

\section{Purpose}

The aim of this study is to examine the work titled "Cumhuriyet Çocuklarına MalûmâtIVataniye", which is a textbook that is directly related to civic and moral education in the Early Republican period and was used as a reference book in schools. It is seen that a limited number of studies were conducted in the literature on the examination of the moral books written during the Republican period. Therefore, this study has a unique importance in terms of remedying this deficiency in the literature and shedding light on contemporary moral education studies.

\section{Method}

This study, which examines civic and moral education in the textbooks of the Early Republican period, is qualitative. The qualitative document analysis method was used in the study. The Content Analysis method was used in the analysis of the data obtained. No samples were used. The entirety of the work titled "Cumhuriyet Çocuklarına Malûmât-ı Vataniye" was included in the study. The work was read after it was transcribed by the researcher and encodings were made. The data revealed at the end of the readings were compared with each other, interpreted and questioned. The data obtained from "Cumhuriyet Çocuklarına Malûmât-ı Vataniye" as a result of the content analysis were encoded under the titles "Social Integration" and "Personal Development". However, many synonyms were detected due to the work in question being written in Ottoman Turkish. Because the frequency values of the words included in the encoding list could not be calculated due to these synonyms, their frequency values were calculated based on the social integration and personal development categories.

\section{Results}

The findings obtained in the study were evaluated under two categories as "General information on "Cumhuriyet Çocuklarına Malûmât-ı Vataniye" and "The features that are intended to be taught to students in "Cumhuriyet Çocuklarına Malûmât-ı Vataniye". In the first title, information on the impressum of the work was included. In the second title, themes were determined under the categories "Social Integration" and "Personal Development", the content analysis of each subject heading was performed and the text was enriched by giving direct quotations to the reader. It was found as a result of the generated frequency and percentage values that the social integration category was more frequently included in the work.

Vales on personal development were included in the book at a rate of $19 \%$. It was detected that information was given under the titles of sense of responsibility, working tirelessly, endeavoring, the importance of saving, good and bad, virtues and contemptible things, adopting good habits and the importance of education in order to guide and contribute to the personal development of students. In addition to this, "Social Integration" was included in the book at a rate of $81 \%$. In this category, it was aimed to integrate students to the society they live in by providing information on rights and obligations, citizenship, acting in cooperation and division of labor, individual and society, citizenship consciousness, municipality, fire authority, streets, and avenues. 


\section{Discussion and Conclusion}

In the work titled "Cumhuriyet Çocuklarına Malûmât-ı Vataniye", it was aimed to raise individuals who are patient, hardworking, moral, socially conscious, aware of their rights and obligations, and responsible towards their family, brothers, friends, and teachers. In other words, it can be said that the values categorized under the titles "Personal Development" and "Social Integration" were attempted to be taught to school-age students in the book. It is frequently emphasized with the topics included in the work that a strong state can only be established with a strong family structure and well-trained and moral individuals. The mental, spiritual and physical well-being of the individual is also listed among the indispensable qualities of a strong state. On the other hand, the state-family dilemma emphasized in "Cumhuriyet Çocuklarına Malumat-ı Vataniye" evokes the idea that the greatest strength of a newly-found state is the establishment of the nation-state structure. In this sense, the textbook titled "Cumhuriyet Çocuklarına Malûmât-ı Vataniye", which forms the basis of our study, appears as a small exemplification of the period in which it was written.

From the subject headings, summaries added at the end of certain subjects and the information provided under the titles of "Words of Wisdom" in "Cumhuriyet Çocuklarına Malûmât-ı Vataniye", which was written in the first years of the Republic, it is understood that the importance of school, family and society in raising a moral generation is frequently emphasized. It is understood from the work that religious elements are not directly referred to in terms of raising moral individuals. It can also be derived that the notion of the moral individual being religious or vice versa was not included in the work. The work did not exceed its purpose of writing. The main ideas of the work were communicated through subjects using an advisory learning approach.

In conclusion, it is apparent that any kind of study on the origins of moral education in Turkey would yield a qualified accumulation. The centralization of national priorities by the state that was attempting to raise strong, qualified generations while building the relationship between the modern world and the desired individual was a policy in accordance with the conditions of the period and therefore it became the priority target of its education system. The work we studied showcases the ideal citizen in the eyes of the Republic by exemplifying the way moral education was established in Turkey within this framework.

\section{Giriş}

II. Meşrutiyet döneminin (1908-1918) son yıllarından itibaren eğitimi belli bir düzene oturtmaya yönelik atılan adımlar artmaya başlamıştır. 1916 yılında toplanan Evkaf Vekaleti'nin elindeki tüm ilkokullar Maarif Nazırlığı'na bağlamıştır. Medreselere ise dokunulamamış, yeni bir dini makam olan Bâb-ı Meşîhat'a bağlanmıştırlar (Başgöz, 2005, s. 92). 1915 yılında 
"Mekatib-i Ibtidaiye-yi Umumiye Talimatnamesi" kabul edilmiş ve bu talimatnamenin uygulanması 1924 yılına kadar devam etmiştir (Cicioğlu, 1982, s. 91).

Cumhuriyet'in ilk Milli Eğitim Bakanlığı ise 20 Mayıs 1920'de Ankara'da kurulmuştur. Fakat Bakanlığın örgüt teşkilatlanması hala yoktur. Çünkü tüm arşivler, dosyalar, binalar ve memurlar İstanbul'da, İstanbul ise işgal altındadır (Başgöz, 2005, s. 67). 15-21 Temmuz 1921 yılında Ankara'da I. Maarif Kongresi, okul ve öğrenci mevduatını tespit etmek, yapılması gerekenleri belirlemek ve eğitime milli bir yön vermek amacıyla toplanmıştır. Maarif kongresi üç toplantı yapmıştır, fakat savaşın devam etmesinden dolayı, gündemindeki tüm konular hakkında derinlemesine çalışma yapılamamıştır (MEB, 2006, s. 9-10). Bu kongre aracılığıyla eğitim sitemimize milli bir yön vermek amaçlanmıştır. Türkiye Cumhuriyeti'nde eğitim alanında yapılan ilk teşkilatlı çalışma ise 15 Temmuz-15 Ağustos 1923 yılında Birinci Heyet-i İlmiye'nin Ankara'da toplanmasıyla gerçekleşmiştir. Dönemin bakanı İsmail Safa Bey'in başkanlığında 25 konu üzerinde görüşme yapılmış ve konulardan birisi de "Din Eğitiminin Esasları"dır (MEB, 2006, s. 11). Fakat bu komisyondaki kişiler "mektepli" ve medreseli" olmak üzere ikiye ayrılmış ve hemen her konuda iki farklı yaklaşımın bir sentezi yapılamadığı için ortak bir sonuca varılamamıştır (Cicioğlu, 1982, s. 33).

3 Mart 1924 yılında kabul edilen Tevhid-i Tedrisat Kanunu ile medreseler kapatılarak birbirlerinden bağımsız hareket eden eğitim kurumları tek çatı altında toplanmıştır. Tevhid-i Tedrisat Kanunu'yla sadece medreseler kapatılmamış aynı zamanda milli duygu ve bilince zarar verme ihtimali olan ülkedeki yabancı okullarında kendilerine düzen vermeleri beklenmiştir. Çünkü Atatürk kendi sınırları içinde hiçbir din ve mezhebin propagandasının yapılmasını istememiştir (Ergün, 1982, s. 55). Eğitim alanında yapılan bir başka önemli toplantı ise 1924 yılında Ankara'da ikinci Heyet-i ilmiye'nin toplanmasıdır. Toplantıda alınan kararların çoğunluğu ise uygulamaya koyulmuştur (MEB, 2006).

Eğitimde laikleşme Cumhuriyet'in temel hedeflerinden birisi olmuştur. Öyle ki laiklik ilkesinin ilk belirtileri de Osmanlı modernleşme sürecinde saklıdır. Söz konusu yenileşme hareketinin ilk kırıntılarına Tanzimat döneminde rastlanmaktadır. Medreselerin yanı sıra açılan modern eğitim kurumları İslam geleneğinden kopmasa da yavaş yavaş bu gelenekten sıyrılmaya ve bağımsız hareket etmeye başlamıştır (Gergeon, 2006, s. 12-13). Cumhuriyet dönemine gelindiğinde ise kavramın içeriği tam anlamıyla doldurulmuştur.

Bu çerçevede Cumhuriyet döneminin ilk öğretim programı 1924 yılında İkinci Heyet-i İlmiye toplantısında alınan kararlar çerçevesinde hazırlanmıştır. Programın en belirgin özelliği kız ve erkek öğrenciler için ayrı programlar hazırlanması ve devrelerin ortadan kaldırılmasıdır. Ayrıca programda dersler arasında bağlantı kurulmamış ve eski programdaki bazı derslerin isimleri de değiştirilmiştir. Örneğin eski programda "Lisan-i Osmaniye" dersi yeni programda "Türkçe" adını alırken, "Musâbahât-ı Ahlâkiye" dersi, yeni programda "Musâbahât-ı Ahlâkiye ve Malûmât-ı Vataniye" adını almıştır. Eski programda ayrı dersler olarak okutulan "Kuran-ı Kerim" ve "Malumat-ı Diniye" dersi de "Kuran-ı Kerim ve Din Dersleri" olarak birleştirilmiştir (Çelenk, Tertemiz ve Kalaycı, 2000, s. 35).

1924 programı üç sene uygulandıktan sonra, öğretmen ve ilgili müfettişlerin raporlarına dayanılarak tarih, coğrafya ve riyaziyat programlarından değişiklik yapılmış ve din dersi de programdan çıkartılmıştır (Cicioğlu, 1982, s. 172). Ayrıca "Musâhabât-ı Ahlâkiye ve Malûmât-ı Vataniye" adlı dersinin müfredatta birinci, ikinci, üçüncü, dördüncü ve beşinci 
sınıflar için haftada 1 saat okutulması kararı alınmıştır. Söz konusu dersin müfredatı genel anlamda ilköğretimin amacını en kapsamlı açıklayacak şekilde biçimlendirilmiştir. Buna göre, ilk mekteplerden mezun olan çocukların büyük bir çoğunluğu öğrenim hayatlarını burada noktalayacakları için, okul sonrası yaşamlarında burada aldıkları eğitimin haricinde konuyla yüz yüze geleceklerdir. Bu yüzden ilk mekteplerde okuyan öğrencilere onları geleceğe hazırlayacak anahtar bilgiler verilerek, iyi yurttaş haline gelebilmeleri sağlanmalıdır (Aslan, 2011, s. 724).

1924 programında "Musâhabât-ı Ahlâkiye ve Malûmât-ı Vataniye" dersinin temel amacı vatan-millet sevgisi ve yurttaşlık bilincini içselleştirmiş, sorumluluk sahibi, ahlaki değerler ve erdemler kazanmış bireyler yetiştirmektedir (Maarif Vekaleti, 1340 (1924)). Müfredatta 1., 2. ve 3. sınıfların ders konuları "Musâhabât-ı Ahlâkiye" konularına; 4. ve 5. sınıflar da ise ders konuları "Malûmât-ı Vataniye" konularına ayrılmıştır. 1924 programında iyi bir yurttaş, Cumhuriyet'in ilkelerine benimseyen, yeni yaşam biçimine ayak uyduran, çevresine ve kendisine fayda sağlayan, ahlaklı ve bilinçli bireylerdir. Programda sadece ahlak kaidelerini öğretmekten öte bu ahlak kaidelerini içselleştirmelerini, yani yaşam biçimleri haline getirmelerini sağlamak önemlidir (Maarif Vekaleti, 1340 (1924), s. 29). Yine programda 4. ve 5. sınıflarda verilen "Malûmât-ı Vataniye" dersi aracılığıyla çocukların sorumlu bir yurttaş olmaları için ülke ve yurt problemleriyle ilgilenmeleri, okulun nasıl işlediğini öğrenmeleri, en iyi yönetim biçiminin vatandaşların söz sahibi oldukları Cumhuriyet yönetimi kavramaları beklenmiştir ("Maarif Vekaleti”, 1340 (1924), s. 36).

27 Aralık 1925 tarihinde Ankara'da Üçüncü Heyet-i İlmiye, dönemin bakanı Mustafa Necati Başkanlığı'nda toplanmıştır. Toplantıda okul kapasitelerinin artırılmasına yönelik çalışmalar yapılması, liselerin yeniden düzenlenmesi ve en önemlisi gündüz eğitim yapan ortaokullarda karma eğitime geçilmesi kararlaştırılmıştır (MEB, 2006). 22 Mart 1926'da "Maarif Teşkilatı Kanunu" ile de Cumhuriyet Dönemi'nin eğitim-öğretim sistemi yeniden düzenlenmiştir.

Talim ve Terbiye Dairesi, 1924 programının çok kısa sürede hazırlandığını ve eksiklerinin olduğunu ifade ederek, Cumhuriyet'in ilkelerine ve yeni öğretim yöntemlerine dayanan 1926 ilk Mektepler Programını altı ay çalışarak oluşturmuştur. Hazırlanan taslak 1925-1926 yılları arasında seçilen okullarda denenmiş ve alınan son kararlar çerçevesinde 1927 yılında tüm ilkokullara uygulanmıştır (Cicioğlu, 1982, s. 95). 1926 tarihli ilk mekteplerin haftalık ders programına baktığımızda "Yurt Bilgisi" dersinin 2. devre dördüncü sınıflarda 2 saat ve beşinci sınıflarda da 1 saat okutulması kararı alınmıştır (“T.C. Maarif Vekaleti”, 1927). 1926 program, yeni Türk alfabesi kabul edilmeden yürürlüğe konduğundan, özellikle, okuma-yazma öğretimi ve Türkçe ders öğretimi konularında değişikliğe uğramıştır. Bundan dolayı 1926 programı, yeni Türk harflerinin uygulandığı ilk program olma özelliğini taşımaktadır (Çelenk, Tertemiz ve Kalaycı, 2000: 40).

1924 programında "Musâhabât-ı Ahlâkiye ve Malûmât-ı Vataniye" dersinin 1926 programında "Yurt Bilgisi" adıyla programa yerleştirildiği göze çarpmaktadır. Söz konusu programda "Yurt Bilgisi" dersinin esas amacı olarak Türkiye'nin genç neslinin "devlet, yurt, 
millet ve milliyet" sevgisine sahip olmaları gösterilmektedir. Programda söz konusu dersin diğer derslerle kurulacak bağlantının harcı olduğu belirtilmektedir (Çelenk, Tertemiz ve Kalaycı, 2000). Ders ile ilgili diğer bir önemli ayak ise çocukların hak ve vazifeler hakkında bilgilendirilmeleri olmuştur. Bu açıklamadan da anlaşılacağı üzere aslında bu ders aracılığıyla çocuklara hukuk kuralları ışığında özgürlük ve sorumluluk alanlarının anlamlandırılması hedeflenmiştir. Yine bu ders sayesinde dini ahlakın sorgusuz sualsiz kabulünden ziyade nedensonuç ilişkisinin işlediği bilimsel ahlakın kazandırılması arzulanmıştır.

Doğrudan "Yurt Bilgisi" dersinin hedeflerinde ahlak eğitimine dair açıklamalara da rastlanılmıştır: "Mektep sıralarını kesmek, duvarları çizmek, arkadaşlara karşı haksı bir harekette bulunmak, kırılmasına sebebiyet verilen bir camı ödemek, dershanenin temizliğine ve intizamına dikkat etmek gibi olaylar ve hareketler yurt bilgisinin içerdiği konulardan birçoğuna iyi bir hareket noktası oluşturur" ("T.C. Maarif Vekaleti", 1930: 80). Yukarıda sıralanan yapılacaklar ve yapılmayacaklar listesi, kuralcı ahlakın belirtilerini içermektedir. Kurallar doğrultusunda çocuklarda doğru-yanlış, iyi-kötü, ahlaklı-ahlaksız gibi eşleştirmelere dair bilinçlerinde şablonların oluşması açısından bu programın ilk adımın atılmasına olanak verdiği söylenebilir.

Programda ayrıca çocukların yaşlarıyla orantılı işlerin sorumluluğunu almalarına izin verilmesi gerektiği üzerinde de durulmaktadır. Dersin hedefleri ve işleniş şekline dair yapılan açıklamaların tümünde dikkat çeken nokta çocukların küçük yaşlardan itibaren özgüvenli, hak ve ödevlerini bilen, sorumluluk alabilen, bilimsel kıstaslar dahilinde hayatın akışan uyum sağlayan, ben duygusunu biz duygusuyla örtüştürmeye başarabilecek bireyler olarak demokratik devletin vatandaşı haline getirilmeye çalışımasıdır ("T.C. Maarif Vekaleti", 1930). Fakat şu da göz ardı edilmemelidir ki, geçiş döneminde hazırlanan bu programlar temel çağdaş dünyaya ayak uydurabilen bireyler yetiştirmeyi hedeflese de geleneksel çizgiden de hemen kopamamıştır. Söz konusu dersin nasıl işleneceğini anlatan bölümün üçüncü kısmında dersin işlenişinde çocukları sorularla düşündürmek adına birtakım örnekler verilmiş ve çocuklar bu soruları birbirlerine sorduklarında dersin uygulamasının da bir anlamda yapılacağı kanaatine varmışlardır. Bu kısımda dikkatleri çeken nokta ise örnek verilen sorulardan ilkinin dini bir içeriğe sahip olması olup bu soru şu şekilde yer almıştır: "Mahallenizdeki çocuklar cuma günlerini nerelerde ve nasıl geçiriyorlar?” ("T.C. Maarif Vekaleti”, 1930: 80).

1926 programında ahlak eğitimiyle dolaylı olarak ilgisi olan "Hayat Bilgisi" dersi de dönemi ahlak eğitiminin araştırılması açısından önemlidir. Programda dersin amacının açıklandığı kısımda eski programda Tabiat Tetkiki, Hıfzıssıhha, Coğrafya ve Tarih Mebadisi, Musâhabât-ı Ahlâkiye ve Malûmât-ı Vataniye derslerinin pek çok yönden birbirleriyle olan bağlantılarından dolayı, ilk mekteplerin birinci devresini oluşturan ilk üç sınıfta "Hayat Bilgisi" adı altında bir derste toplandığından bahsedilmektedir. Dersin hedefleri arasında gösterilen 5. madde de ise okul, aile ve şehir yaşamında insanlar arasında meydana gelen gerçek olaylar tartışılacak ya da hayali masallar ve hikâyelerle aracılığıyla çocuklarda "ahlaki telkinlerde" bulunulmasının sağlanacağından bahsedilmektedir ("T.C. Maarif Vekaleti", 1930, s. 7). "Hayat Bilgisi" dersinden de ahlaki bir bilinç oluşturarak yaşadığı çevrenin farkında, sorumluluklarının bilincinde, soyut kavramları (doğru, yanlış, iyi, kötü, güzel, ahlaklı, ahlaksız) somut örüntüler aracılı̆ıyla irdeleyebilen çocukların yetişmesi amaçlanmıştır ("T.C. Maarif Vekaleti”, 1927). Ayrıca dersin nasıl işleneceğinin anlatıldığı kısımda da mektebi temiz tutmak, çamurlu 
ayakkabılarla sınıfa girmemek, sınıfları kirletmemek, sınıftaki eşyalara zarar vermemek gerektiğini anlatan açıklamalarda da anlayacağımı üzere, görgü kuralları, toplumsal kurallar ve birlikte yaşamanın gerektirdiği sorumluluklar küçük yaşlardan itibaren çocuklara aşılanmaya çalışılmaktadır.

Hayat Bilgisi 1. sınıf ders programının kış ayı için hazırlanan içerik programında da ahlaksal kurallara rastlanılmaktadır. Örneğin programdaki bazı konu başlıkları şu şekildedir: "Kışın Açıkta Çalışan insanlar (muhite göre): Kayıkçılar, Gemiciler, Amele, Polis, Bekçi. Bunların Çalışmalarından Bizim Kazandığımız Rahat. Insanların Birbirine Yardımı" ("T.C. Maarif Vekaleti", 1930, s. 16). Ayrıca yardımlaşma ve her mesleğin toplumun düzen ve huzuru için ne kadar gerekli olduğu ve küçümsenmemesi gerektiği ana fikri çocuklara aşılanarak yardımlaşma, ötekine saygı, hoşgörü gibi modern insanı bugün de ahlaki kılacak soyut duygular somut hale getirilmeye çalışılmıştır. 1926 programının sonunda beşinci sınıflara ailelerin isteği doğrultusunda din dersinin de verileceğine dair bir açıklama bulunmaktadır. Elbette ki hayat bilgisi dersine dair bazı kaygıların öğretilme kaygısı, yalnızca devlet eksenli çabalarda saklı olduğu düşünülmemelidir. Aslında pek çok eğitimli insan yazdıkları küçük, orta boy eserler ile hayat bilgisini kazandırmaya çalışmıştır. Örneğin Lorrin Shepard tarafından 1927 yılında kaleme alınan "Sıhhi Konuşuk" adlı eser, halka sağlık bilgisini sağlık bilgisi düzleminde de bir nevi hayat bilgisini sade bir dil ile anlatmaya çalışmıştır (Akagündüz Ü. , 2016, s. 768). Öte yandan Üstel'e göre "Malûmât-ı Vataniye" ve "Yurt Bilgisi" ders kitaplarıyla iki ana eksen üzerinde hareket etmektedir: Medenilik ve Yurtseverlik (Üstel, 2009, s. 174-175).

Tüm bunlardan hareketle çalışmanın ana eksenini oluşturan "Cumhuriyet Çocuklarına Malûmât-ı Vataniye" ders kitabı, dönemin eğitim ve ahlak felsefesi geleneğinin detaylandırılması ve aydınlatılması noktasında önemli bir boşluğu doldurmaktadır. Bu çerçevede araştırmanın amacı, Erken Cumhuriyet döneminde yurttaşlık ve ahlak eğitimiyle doğrudan ilgili bir ders kitabı olan "Cumhuriyet Çocuklarına Malûmât-ı Vataniye" adlı eserin incelenmesidir. Bu bağlamda eserin alt problemleri şöyle belirlenmiştir: Eserin genel özellikler nedir? Eserde bireylere kazandırıması istenilen özellikler nelerdir? Sorularına cevap aranmıştır.

\section{Yöntem}

Erken Cumhuriyet döneminde ders kitaplarında yurttaşlık ve ahlak eğitimini inceleyen bu çalışma nitel bir araştırmadır. Çalışmada nitel araştırma yöntemlerinden doküman inceleme yöntemi kullanılmıştır. Doküman incelemesi, araştırılması planlanan olay ya da olgular hakkında bilgi içeren yazılı dokümanların analizinden oluşmaktadır (Yıldırım ve Şimşek, 2006, s. 187). Çalışmanın veri kaynağını 1926 baskılı "Cumhuriyet Çocuklarına Malûmât-ı Vataniye" adlı ders kitabı oluşturmaktadır. Araştırmada kullanılan verilerin ders kitaplarının analizi yoluyla temin edildiği bu çalışma Etik Kurul Onayı gerektirmemektedir. 
Elde edilen verilerin çözümlenmesinde İçerik Analizi yöntemi kullanılmıştır. İçerik analizinde temelde yapılan işlem ise, birbirine benzeyen verileri belirli kavramlar ve temalar çerçevesinde bir araya getirmek ve bunları okuyucunun anlayabileceği bir biçimde düzenleyerek yorumlamaktır (Yıldırım ve Şimşek, 2006, s. 27). "Cumhuriyet Çocuklarına Malûmât-ı Vataniye" adlı eserin incelenmesinde hareket noktası olarak eserde geçen değerler kabul edilmiştir. Eserde yer edinen tüm değerler cümleler düzeyinde değerlendirilerek yurttaşlık ve ahlak eğitimine doğrudan ya da dolaylı olarak gönderme yapan değerler incelenmiştir. Araştırmada örneklem kullanılmamıştır. Çalışmaya "Cumhuriyet Çocuklarına Malûmât-ı Vataniye" adlı eserin tamamı dâhil edilmiştir. Eser, araştırmacı tarafından transkripsiyonu yapıldıktan sonra ortaya çıkan veriler, birbirleriyle karşılaştırılarak, yorumlanmıştır.

Kitaptaki metinlerin içerik analizi sonucunda yurttaşlık ve ahlak eğitimine ilişkin belirlenen değerlerden hareketle kodlama listesi oluşturulmuş ve konu başlıkları esas alınarak "Toplumsal Uyum" ve "Bireysel Gelişim" temaları içerinde yer alma durumuna göre kategorilendirilmiştir. Ancak söz konusu eserin Osmanlıca ile kaleme alınmasından dolayı pek çok eş anlamlı kelime tespit edilmiştir. Bu eş anlamlı kelimeler dolayısıyla kodlama listesinde yer alan kelimelerin frekans değerleri hesaplanamadığından sadece kategorilerin yüzde değerleri hesaplanabilmiştir.

\section{Bulgular}

Araştırmada elde edilen bulgular "Cumhuriyet Çocuklarına Malûmât-ı Vataniye ile ilgili Genel Bilgiler", "Cumhuriyet Çocuklarına Malûmât-ı Vataniye'de Kazandırılmak İstenen Özellikler" olmak üzere iki başlıkta incelenmiştir.

\section{Cumhuriyet Çocuklarına Malûmât-ı Vataniye ile ilgili Genel Bilgiler}

Muslihiddin Adil tarafından 1926 tarihinde yazılan ve İstanbul'da Orhaniye Matbaası'nda basılan "Cumhuriyet Çocuklarına Malûmât-ı Vataniye" adlı eser 107 sayfadan oluşmaktadır. Eserin kapağında en üstte ilk Mektep-Dördüncü Sınıf ibareleri yer almakta, kitabın isminden sonra "Mütehassıs komisyonun raporu üzerine milli talim ve terbiye dairesinin 1926 numarası ve 24 Ağustos tarihli kararı ile mektepler kabul edilmiştir" ifadesi bulunmaktadır (Kitap kapağı için bakınız Ek-1). Eserin yazarı ise "Darülfünun Mukayeseli Hukuk-ı Idare Müdürü" şeklinde okuyucuya tanıtılmıştır. 107 sayfalık esere iç kapaktan sonra, ikinci sayfada Muslihiddin Adil'in kaleme aldığı eserlerin listesi verilerek başlanmıştır. Üçüncü sayfada müfredat programı başlığı adı altında, dersin haftada bir saat verileceği belirtilerek, bu sayfadan itibaren eserin konuları anlatılmaya başlamıştır. 107 sayfalık eserin 105 sayfası konulara ayrılmıştır. Konular anlatılırken nasihat ya da öğüt verme bir tür öğrenim yaklaşımı olarak kullanılmıştır. Yazar, bazı konulardan sonra "Hülasa: Öğrenilecek Noktalar ve Sualler" başlıklı kısımlar vererek öğrencilerin anlama düzeyini belirlemeye çalışmıştır.

Eserin 19. sayfasında Mustafa Kemal Atatürk'ün fotoğrafına yer verilmiştir (Kitabın iç sayfaları için bakınız Ek-2). Bazı konular anlatılırken "Güzel Sözler" başlığı altında atasözü ve 
deyimlere yer verilmiştir. Güzel Sözler başlığına dipnot düşülerek yazar tarafından şu açıklamaya yer verilmiştir: "Muallim bu sözleri izah ve istihzah etmelidir" (Adil, 1926: 44). Kitapta içindekiler listesi olmadığından bölümler, yer alma sırasına ve sayfa numarasına göre aşağıdaki tabloda gösterilmiştir.

Tablo 1

Cumhuriyet Çocuklarına Malûmât-ı Vataniye'de Yer Alan Metinler

\begin{tabular}{llr}
\hline Sıra & \multicolumn{1}{c}{ Başlık } & Sayfa \\
\hline 1 & Ferd ve Cemiyet & 9 \\
3 & Sa'y: Sa'yın Ehemmiyeti & 15 \\
4 & Meram & 17 \\
5 & Devam ve Sebat & 19 \\
6 & Teşarük ve Tesanüd: İş Bölümü & 22 \\
7 & Hak ve Vazife & 28 \\
8 & Mesuliyyet & 28 \\
9 & Hayır ve Şer & 31 \\
10 & Fazilet ve Reziliyyet & 33 \\
11 & Hak ve Vazifelerimiz & 36 \\
12 & Hayat ve Sıhhatin Muhafazası: Nefsimize Karşı Vazifelerimiz \\
13 & illm-i Tahsil & 37 \\
14 & Seciyye & 38 \\
15 & Tasarruf & 41 \\
17 & Ailemize Karşı Vazifelerimiz & 45 \\
18 & Kardeşlerimize Dostlarımıza ve Muallimlerimize Karşı Vazifelerimiz & 47 \\
19 & Milletimize Karşı Vazifelerimiz & 52 \\
20 & Beşeriyete Karşı Vazifelerimiz & 60 \\
21 & Hemşerilik Vazifeleri & 69 \\
22 & Belediyeler & 73 \\
24 & Vatandaşlara Teveccüh Eden Vazifeler & 77 \\
25 & Ev Dahilinde Sıhhi Temizlik & 83 \\
26 & Belediyelerin Teşrik-i Mesaisi & 86 \\
27 & İtfaiye Teşkilatının Ehemmiyeti & 89 \\
28 & Sokaklar ve Umumi Caddeler & 95 \\
29 & Sokak ve Caddelerin İyi Bir Halde Muhafazası & 91 \\
30 & Halkın Tenzihine Hıdmet & 95 \\
31 & Fukara ve Muhtaçlara Yardım & 97 \\
32 & Umumun Menfaatine Yarayan Teşkilatı & 107 \\
33 & Vatandaşları Himaye &
\end{tabular}

Eserde içindekiler listesi olmamasına rağmen, yukarıda başlıkları verilen metinlerle ne anlatılmak istenildiği "Ferd ve Cemiyet" konusu anlatılmadan üçüncü ve dördüncü sayfalarda kısaca açıklanmıştır. Bu sayfa aralığında anlatılanları esere giriş olarak değerlendirmek 
mümkündür. Muslihiddin Adil bir musahabeden önce neden o konuyu seçtiğini ve amacının ne olduğunu açıklayarak anlatımına başlamaktadır. Eserde içindekiler listesi, giriş ve sonuç kısımlarına yer verilmemiştir.

\section{Cumhuriyet Çocuklarına Malûmât-ı Vataniye'de Kazandırılmak İstenen Özellikler}

Cumhuriyet Çocuklarına Malûmât-ı Vataniye'de öğrencilere kazandırılmak istenilen ahlak eğitimiyle ilgili temel değerleri belirlemek için her metin için içerik analizi yapılmıştır. Kitapta yer alan metinlerin incelenmesi sonucu oluşan içerik analizi tablosu aşağıda gösterilmiştir (Alabaş, 2018). ${ }^{1}$

Tablo 2

Cumhuriyet Çocuklarına Malûmât-ı Vataniye'de Değerler

\begin{tabular}{lcc}
\hline Musahabe Başlığı & Değer & Oran \\
\hline 1- Sa'y: Sa'yın Ehemmiyeti Meram, 2- Devam ve Sebat, 3- & & \\
Mesuliyyet, Hayır ve Şer, Fazilet ve Reziliyyet, 4- Hayat ve & Bireysel Gelişim & $\% 19$ \\
Sıhhatin Muhafazası: Nefsimize Karşı Vazifelerimiz, 5- Illm-i & & \\
Tahsil, 6- Seciyye, 7- Tasarruf & & \\
\hline 1- Ferd ve Cemiyet, 2- Teşarük ve Tesanüd: İş Bölümü, 3- Hak & & \\
ve Vazife, 4- Ailemize Karşı Vazifelerimiz, 5- Kardeşlerimize & & \\
Dostlarımıza ve Muallimlerimize Karşı Vazifelerimiz, 6- & Toplumsal Uyum & \%81 \\
Milletimize Karşı Vazifelerimiz, 7- Beşeriyete Karşı & & \\
Vazifelerimiz, 8- Hemşerilik Vazifeleri, 9- Belediyeler, 10- & \\
Vatandaşlara Teveccüh Eden Vazifeler, 11- İtfaiye Teşkilatının & & \\
Ehemmiyeti, 12- Sokaklar ve Umumi Caddeler, 13- Halkın & & \\
Tenzihine Hıdmet, 14- Fukara ve Muhtaçlara Yardım, 15- & & \\
Umumun Menfaatine Yarayan Teşkilatı, 16- Vatandaşları & \\
Himaye & & \\
\hline
\end{tabular}

Yukarıdaki tabloda da görüldüğü gibi “Cumhuriyet Çocuklarına Malûmât-ı Vataniye"de okul aracılığıyla öğrencilere kazandırılması amaçlanan yurttaşlık ve ahlak eğitimine ilişkin değerler "Bireysel Gelişim ve Toplumsal Uyum" kategorilerinde ortaya çıkmıştır. Kitapta bireysel gelişim ile ilgili değerlere \%19 oranında yer verilmiştir. Öğrencilerin bireysel gelişimlerine katkı sağlamak ve yönlendirmek amacıyla, sorumluluk alma duygusu, usanmadan çalışmaya devam etmek, emek vermek, tasarrufun önemi, iyi ve kötü, erdemler ve rezil şeyler, iyi alışkanlıklar edinmek, eğitim ve öğretimin önemi başlıklarında açıklamalarda bulunulduğu tespit edilmiştir.

Bunun yanı sıra kitapta "Toplumsal Uyum" \%81 oranında yer tutmuştur. Bu kategoride de hak ve vazifelerimiz, hemşerilik, iş birliği ve iş bölümü içerisinde hareket etmek, fert ve cemiyet, vatandaşlık bilinci, belediye, itfaiye, sokak ve caddeler hakkında bilgi verilerek öğrencilerin yaşadıkları topluma uyum sağlamaları amaçlanmıştır.

\footnotetext{
1 İçerik Analizi tablosu oluşturulurken kategorilerin oluşturulmasında Ramazan Alabaş'ın “Cumhuriyet'in İlk Yıllarında Illk Mekteplerde İnsani ve Toplumsal Değerler Eğitimi: Resimli Yeni Musabâhat-ı Ahlâkiye ve Medeniye Ders Kitabı Örneği" adlı makalesinden yararlanılmıştır.
} 


\section{Bireysel Gelişim}

Cumhuriyet Çocuklarına Malûmât-ı Vataniye'de bireysel gelişim kategorisinde gruplandırılan içerikler, öğrencinin kişilik ve ahlakının gelişimini desteklemeye yönelik açıklamalarıyla dikkat çekmektedir. Bireysel gelişim kategorisinin ilk teması olan "Sa'yı" yazar şöyle açıklamaktadır (Adil, 1926, s. 12):

Evlatlarım hayat başlı başına bir kavgadır. Beşikten mezara kadar çarpışacağız. Fakat bu çarpışmada behemehal galip gelmeliyiz. Bu ise ancak çalışma ile olur. Medeni alemde gördüğümüz bütün eserler, keşifler, icatlar hep insanların çalışması ile husule gelmiştir. Bugün gördüğümüz şimendiferleri, tahtü'l bahrleri, tayyareleri, vapurları, otomobilleri, telsiz telefonları hep insanlar çalışarak yapmışlardır. Eğer çalışmasalardı bu eserler vücut bulamazdı. İşte insanların ihtiyaçlarını başarabilmek için sarf ettikleri gayret ve emeğe sa'y denir.

Bireysel gelişim başlığı altında incelediğimiz sa'y, kişinin çalışırken haz duymasının ve kendisine yarar sağlamasının yanı sıra vatanın birlik, beraberlik ve gelişimine sağladığı katkıdan dolayı da ayrı bir önem arz etmektedir. Yazar, eserinde "Devamlı ve Sürekli" bir şekilde çalışan insanların her zaman başarılı olduğunu ifade ederek, Cristof Columb'un Amerika'yı keşfederken ne kadar zorluk çektiğini örneklemiştir (Adil, 1926, s. 13). Öte yandan yazar, sa'yın bir başka önemini ise kişiye hürriyet sunmasında görmektedir. Sadece çalışkan insanların hürriyete malik olacaklarını ifade etmektedir. İstiklal Savaşı'nda başarılı olan Türk milletinin elindeki temel unsurun bıkmadan yılmadan çalışması olduğunu söyleyen yazar, iyi vatandaş olmanın da çok çalışmaktan, usanmamaktan geçtiğini sözlerine eklemektedir. Bireysel gelişim kategorisi altında incelediğimiz emeğin bir ayağı ise toplumsal uyum kategorisine de girdiği bu açıklamalardan anlaşılmaktadır. Yazar son olarak muhasebesini bazı güzel sözler başlı̆̆ı altında şu deyim ve atasözlerine yer vermiştir (Adil, 1926, s. 14):

İşleyen demir paslanmaz.

Tembele iş buyur, sana akıl öğretsin.

Yapmak güç yıkmak kolaydır.

Yalnız ümitle geçinen açlıktan ölür.

Çalışmak günü kısaltır, ömrü uzatır.

Çalışmak faziletin bekçisidir.

Bireysel gelişim kategorisi altında incelediğimiz bir diğer konunun başlığı ise meramdır. Eserde aklımızın hükmettiği iyi şeyi yapmak olarak tanımlanan "Meram" konusu eserde, öğrencilere hayatta insanın bir amacının olmasının neden zorunlu olduğuna dair bilgiler verilmesi amacıyla yazıldığı anlaşılmaktadır (Adil, 1926, s. 15). Sa’y başlığında olduğu gibi meram konusunun sonunda öğrencilere "Hülasa: Öğrenilecek Noktalar" ve "Sualler" başlığı altında, konuyu daha iyi anlayabilmeleri için sorular sorulmuştur. Yazar, meram başlığının devamında "Devam ve Sebat" başlığı altında meramın başarıda tek başına yeterli olmadığını vurgulamıştır (Adil, 1926, s. 17-18). Her hakkın karşısında bir vazife ve her vazifenin karşısında 
da mesuliyet olduğunu söyleyen yazar, kişinin nefsine, ailesine, vatanına, insanlığa ve yaşadığı halka karşı sorumluluklarının olduğunu dile getirmektedir (Adil, 1926, s. 28). "Mesuliyyet" konusunun hemen altında "Hayır ve Şer" başlığında öğrencilerin bireysel gelişimleri desteklenerek şu ifadelere yer verilmiştir (Adil, 1926, s. 28-29):

İnsan için hayatta yalnız bir doğru yol vardır. O da hayır yani iyiliktir. Ne zevkimiz ne menfaatimiz ne duygularımız hayatta bize rehber olamaz. Kendimize zevkimizi rehber olarak kabul edersek, hayvan derecesine ineriz. Çünkü insan zevk için yaratılmamıştır. Bilakis kendisine, ailesine, vatanına ve insaniyete karşı vazifesi ifası için yaratılmıştır... İyi duygularda bazen bizi iyiliğe teşvik eder. Fakat duygularımız da kendimize rehber tutmayız. Çünkü duygularımız bazen bizi aldatabilir. Hasılı evlatlarım hayatta bizim rehberimiz hayır, iyilik olmalıdır.

Eserde hayır bu şekilde anlatıldıktan sonra "Şer" ise insanın vazifelerini yapmaması olarak açıklanmıştır. Yazar, şerin insanı küçük düşüreceğini, fena insanları kimsenin sevmeyeceğini ve zor durumda kaldıklarında da kimsenin onlara yardım etmeyeceklerini söylemektedir (Adil, 1926, s. 30). Hayır işleyenlerin fazilet sahibi yani erdemli kişiler olduğunu belirten yazar, eserinde öğrencilerin bireysel gelişim ya da karakterlerinin oluşmasında temele aldığı değerleri de bir yandan öğrencilere aktarmaya devam etmektedir. "Fazilet ve Rezilliyet" konu başlı̆ı̆ın sonunda "Hülasa: Öğrenilecek Noktalar" başlığı altında şu açıklamalara da yer verilmiştir (Adil, 1926, s. 31):

Insan için hayatta en doğru yol iyiliktir.

Fenalık insanın vazifelerini yapmaması demektir.

Hayırlı insanlar fazilet sahibi kimselerdir.

Fazilet sahipleri her yerde hürmet görür.

Fena insanların varacakları akıbet rezilliktir.

Muslihiddin Adil, insanın kendisine karşı en büyük görevinin hayat ve sıhhatini korumak olduğu iddia etmektedir. Çünkü sağlığına dikkat etmeyen bir insan vazifelerini yerine getiremeyeceğinden faziletli bir insan olma şansına sahip olamazdı. Yazar, bu konuda eserinde şu açıklamalara yer vermiştir: "Kalbimizin intizamlı işleyebilmesi temiz bir kan ile sulanmasına bağlıdır. Bu ise yemek, içmek, giyinmek hava vesair hususlarda hıfzıssıhha kaidelerine riayet etmekle olabilir. Hasılı insanın birinci vazifesi mümkün olduğu kadar iyi yaşamak için lazım geleni yapmaktır. Sağlam olmayan vücudu hiçbir vakit mesut olamaz" (Adil, 1926, s. 36).

Nefsimize karşı olan vazifelerimizden bir diğerinin ise "ilm-i Tahsil”" yani eğitim olduğu söylenerek, cahil insanın şerefli olmadığı, dünyada her zenginliği, mutluluğu iktidarı meydana getirenin ilim olduğu belirtilerek meyvesiz ağaç ile ilimsiz insan arasında analoji yapılmıştır (Adil, 1926, s. 37).

Bireysel gelişim kategorisinde incelediğimiz "ilm-i Tahsil” konu başlığıyla yazar bir yandan da kaleme aldığı eseri yazma amacını da ifade etmektedir. Öğrencilerin öncelikle vatan ve sonrasında dünya hakkında bilgilere sahip olmaları için, kendi lisanlarıyla öğrenmeye mecbur olduklarını ve "Malûmât-ı Vataniye" dersinin de bu anlamda önemli olduğunu belirtmektedir. Bireysel gelişim kategorisinde incelediğimiz bir diğer konu ise "Secciye" başığını taşımaktadır. Karakter, huy anlamlarında kullandığımız "Seciyye", insanın zeka, 
malumat, meram gibi kabiliyetlerinin bir sonucu olarak gösterilerek, iyi bir seciyeye sahip olmak için kişinin küçük yaştan itibaren duygularını ve zihnini terbiye etmesi gerektiğini belirtilmektedir. Öte tandan eserde "milli seciyye" şöyle açıklanmaktadır (Adil, 1926, s. 38):

Milli Seciyye: Her insanın kendine mahsus seciyesi olduğu gibi her milletin hususi bir seciyesi vardır. Milletlerin bu hususi seciyelerine milli seciyye denir. Bir millet efradının kabiliyetçe müşterek oldukları noktalar o milletin seciyesidir. Misal Türklerin seciyesini araştırırsak görürüz ki Türkler cesur ve cengâver millettir. Asabi olmaktan ziyade soğuk kanlıdır, namus ve şereflerini muhafaza etmek için hiçbir fedakarlığı yapmaktan çekinmezler. Misafire karşı fevkalade mükerrerdir. İtaatlidir son derece iyi kalpli ve meramında son derece kuvvetlidir. Türkler tarihte azim ve meramlarıyla şöhret kazanmışlardır. Türklerin büyük ve şiddetli zekâsı medeniyete birçok eserler vermiştir.

Bireysel gelişim kategorisinde incelediğimiz son konu ise "Tasarruf" başlığını taşımaktadır. Eserde nefsimize karşı yapacağımız görevlerden bir tanesi olarak gösterilen tasarrufun sadece kişinin kendisi için değil yaşadığı topluma faydalı olması açısından da önemli olduğu dile getirilmektedir (Adil, 1926, s. 41). Tasarrufun düşmanları olarak ise şunlar sayılmıştır: Kumar, Tütün, İçki. Yazar, kumara dayanabilecek hiçbir servetin olmadığı, birkaç saatlik kumarın kişinin tüm istikbalini ve saadetini yok edebileceğine vurgulayarak kumarın kanunen yasak olduğunu hatırlatmaktadır. Öte yandan içki de tasarrufun düşmanı olarak gösterilmektedir. İçkiye müptela olan birisinin parasını, sağlığını ve saadetini kaybedeceği söylenmektedir. Benzer şekilde tütünün de bir masraf kapısı olduğu ve kişinin sağlığını tehlikeye attığı anlatılmıştır (Adil, 1926, s. 42). Tasarruf konusunun sonunda "Güzel Sözler" başlığı altında bazı atasözü ve deyimlere yer verilmiştir. Bunlar (Adil, 1926, s. 44).

Ne ekersek onu biçeriz.

Bu sıcağa kar dayanmaz.

Hazır yiyen dağılır dayanmaz.

Azı bilmeyen çoğu hiç bilemez.

Az veren candan çok veren maldan verir

Artık mal göz çıkartmaz.

Parayı para kazanır.

Akakça kara gün gün içindir.

Küçük parçaları sakla altınlar kendi saklanır.

\section{Toplumsal Uyum}

"Cumhuriyet Çocuklarına Malûmât-ı Vataniye"de, "Toplumsal Uyum" kategorisinde gruplandırılan içeriklerde, öncelikle öğrencinin yaşadığı toplumu tanıması ve sonrasında da çağına ayak uyduran, hak ve vazifelerinin bilinciyle hareket eden bireyler haline gelmeleri olduğu anlaşılmaktadır. Yazar, toplumsal uyum kategorisinin ilk teması olan "Fert ve Cemiyet" konu başığıyla, öğrencilere içinde yaşadıkları toplum hayatını öğretmeyi amaçladığını söylemektedir. Eski zamanlara gönderme yaparak, inanların söz konusu dönemde hayvanlar 
gibi yaşadığını ve güçlü olanın güçsüz olanı ezerek, her zaman onun sesinin duyulduğunu belirtmektedir (Adil, 1926, s. 5). Topluluk ya da toplum fikrinin eski insanlarda düşmanlarla mücadele karşısında güçlerini birleştirme isteğinden doğduğunu söyleyen yazar, metnin sonunda "Hülasa" diyerek, insanların cemiyetle ve cemiyetten ayrı yaşayamayacağını söylemekte ve cemiyetlerinde insanların birbirine olan yardımıyla baki kalabileceğini belirtmektedir (Adil, 1926, s. 5).

Toplumsal uyum kategorisinin ve metnin ilk konusu olan "Fert ve Cemiyet" başlığı eserde detaylı anlatılan konular arasında sayılabilir. Yazar, sözlerine "Ferdin Cemiyet Medyun Olduğu Nimetler" adında yeni bir konu başlığı açarak toplumsal yaşamın önemini vurgulamaya devam etmektedir. Öte yandan yazar diğer uygarlıklarla da kıyaslama yaparak, bugün medeni kabul edilen Avrupa halkının da insanının taş, silahlar ve kemik aletler kullanan vahşilerin neslinden geldiğini eklemektedir. Yazara göre ilk insanlar topluluk halinde yaşayarak güçlenmiş bu sayede de uygarlık ateşini yakmışlardır. Yazar, insanların yerleşik yaşama geçmeleriyle medeniyetin ilerlediğini, avcı-toplayıcı hayatın sona erdiğini, aile hayatının başladığını belirtmiştir. Ayrıca eserde, toplumsal yaşamın iş bölümü sayesinde insanlara pek çok nimet verdiği, o olmasaydı ne ekmek ne de giydiğimiz giysilerin olacağı vurgulanmaktadır (Adil, 1926, s. 6-7).

Yazar "Fert ve Cemiyet" konusunun sonunda "Hülasa: Öğrenilecek Noktalar" başlığıyla "Fert ve Cemiyet" konusunu aynı kelimelerle özetleyerek "Sualler" başlığıyla öğrencilerin şu soruları yanıtlamalarını beklemektedir (Adil, 1926, s. 12): "Insan niçin cemiyetten ayrı yaşayamaz? Cemiyet nasıl başlayabilir? insanlar medeni hayata erişmek için ne türlü hayat geçirmişlerdir? Cemiyetin insana verdiği nimetler nedir? iptidai insanlarla bugünkü insanlar arasında ne farklar vardır? Bugünkü Türkiye'nin evladı olduğunuz için seviniyor musunuz niçin?" Sorulardan da anlaşılacağı üzere yazar, öğrencilere sorduğu soruların cevaplarının metinden bulunabilirliğine dikkat etmiştir. Anlatılan konu dışında bilgi istenilmemektedir. Sorular, öğrencinin anlatılanlar arasında mantıksal akıl yürütmelerde bulunmasına imkân vermektedir.

“Toplumsal Uyum" kategorisinin bir diğer konusu ise "Teşarük ve Tesanüd: İş Bölümü" başığını taşımaktadır. Çalışmanın kişiye sağladığı yararlardan diğer konularda (Devam ve Sebat) bahseden yazar, bazı işlerin birlikte çalışılarak iş bölümü içerisinde yapıldığında daha az zamanda daha hızı yol alındığını belirtmiştir (Adil, 1926, s. 19-20). Eserde, iş bölümü bireylerin topluma uyum sağlaması ve birlikte yaşama kültürüne ulaşması noktasında önemli bir konu olarak kabul edilmektedir. Konu başlığının sonunda "Hülasa: Öğrenilecek Noktalar" ve "Sualler" başlıklarına yer verilerek konu tamamlanmıştır.

"Toplumsal Uyum" kategorisinin bir sonraki teması ise "Hak ve Vazife" başlığını taşımaktadır. "Hak ve Vazife" konusu kendi içinde alt başılılar halinde bir bütün olarak ele alınmaya çalışmıştır. Öncelikle hak ve vazife kavramları eserde şöyle tanımlanarak öğrencilerin tanım düzeyinde ilk bilgiye ulaşmaları amaçlanmıştır: “... hak cemiyet halinde yaşayan insanlar için yine o cemiyet tarafından konmuş bir kaidedir. Bu kaideyi bozmak isteyenler için ayrıca cezalarda tayin olunmuştur. Hak olunca vazifede vardır. Yani hak ve vazife karşılıklıdır. Ben başkasının hakkına riayet ediyorum. Bu vazifemdir. Fakat başkasının da benim hakkıma tecavüz etmemesini istemem hakdır" (Adil, 1926, s. 22). Kişinin hak ve vazifesini kendi kendine 
bilebileceğini söyleyen yazar, kanunların bize emretmediği bazı şeyleri vicdanımızın sesini dinleyerek yerine getirdiğimizi söylemektedir. Örneğin kanunlar fakirlere sadaka vermeyi emretmemiştir, ancak insanlar bunu bir ahlaki borç olarak görmüşlerdir (Adil, 1926, s. 23). Öte yandan yazar tarafından vazifenin düşmanları olarak nitelendirilen menfaatler ve ihtiraslar da kişiyi vazifeden alıkoyabilmektedir. Vazifenin düşmanları olduğu gibi bekçileri de olduğu belirtilen eserde, bu bekçiler sırasıyla şöyle sayılmıştır: Vicdan, Halkın Düşünüşü (efkar-ı amme), Sıhhatimizi Korumak Düşüncesi, Kanunlar ve son olarak da Din (Adil, 1926, s. 26-27). Benzer şekilde bu konu başlığının sonunda da "Hülasa: Öğrenilecek Noktalar ve Sualler" başlıklarına yer verilerek açıklanan konu detaylandırılmıştır.

"Hak ve Vazife" konu başlığı incelenen eserde en çok detaylandırılan konu olma özelliğine sahiptir. Eserde ailemize, kardeşlerimize, dostlarımıza, muallimlerimize, milletimize, beşeriyete karşı vazifelerimiz hakkında açıklamalarda bulunularak öğrencilerin yaşadığı topluma ayak uydurmaları, hak ve vazifelerinin bilincinde olmaları ve topluma fayda sağlayan bireyler olarak yetişmeleri amaçlanmıştır. Bu çerçevede yazar, "Ailemize Karşı Vazifelerimiz" başlığı altında, aile ve devlet arasında ilişki kurarak, sağlam ailelerin güçlü devletler yaratacağını ifade etmekte ve yazar sözlerine şöyle devam etmektedir: "Anne babalarınız her zor zamanda nasıl yanınızda olarak size yardım ettiyse, sizin vazifenizde onların her muhtaç olduğu zamanda koşarak yanlarında olmaktır" (Adil, 1926, s. 45-46). Yazar, çocukların ailelerine karşı vazifelerini ise şu sözlerle anlatmaktadır (Adil, 1926):

Her evlad ana babasına itâate dahi mecburdur. Onların sözünden dışarıya çıkmamak ana babayı muktedir etmeye en büyük bir borçtur. Bir insan tahsili ilerledikçe kendini ana ve babasından daha iyi düşünmeğe muktedir görebilir... Ana baba evlad kadar tahsil görmemiş olsa bile akıl ve muhakemeleri yerindedir. Ve çocuklarını kendilerinden bile daha ziyade sevdiklerinden onları doğru yol sevk etmeye çalışırlar. Küçük dostlarım hayatta en büyük saadet nedir biliyor musunuz? Hayatın en büyük saadeti bizi yetiştiren bize karşı hiçbir fedakarlıktan çekinmeyen ana ve babamıza karşı kadirşinas olmamızdır. Ve babamızı mesut görmekle kalbimizden duyacağı saadetin hududu yoktur.

Benzer şekilde eserde, kardeşlerimizin, dostlarımızın, öğretmenlerimizin yardıma ihtiyaçları olduğunda yanlarında olmamız gerektiği de anlatılmaktadır. Örneğin yazar, öğretmenlere hürmet noktasında şunları söylemektedir (Adil, 1926, s. 50): “Muallimlerimize hürmet ederken ilme de hürmet etmiş oluruz. Insanın kadir ve kıymetini yükselten şey ilim ve maariftir. Onu ise bize muallim öğretir. Muallim bize daha iyi bir şeref verir. O halde muallimler bizim hürmet ve hizmetimize her suretle layıktırlar."

Eserde "Toplumsal Uyum" kategorisi içinde incelediğimiz bir başka konu ise "Milletimize Karşı Vazifelerimiz" başlığını taşımaktadır. Adı geçen konu eserde şu dört alt başlıkta incelenmektedir: vatan-millet, kanuna itaat, askerlik ve mebusların intihabı. Öğrencilere bu konu başlığı anlatılırken öncelikle vatan nedir? Sorusuna yanıt aranarak tanımlaması şöyle yapılmıştır (Adil, 1926, s. 52): “Vatan yalnız doğduğumuz şehir veya kasaba 
değildir. Vatan bundan çok daha büyüktür. Vatan bütün devlettir. Bizim cedlerimizin yaşadığı şu güzel ve feyzli topraklar bu her şeyden her memleketten güzel olan yerler bunlar vatanımızdır. Her vatandaşın en mukaddes vazifesi vatanını sevmek ve ona karşı ömrünün son dakikasına kadar hizmet etmektir." Dönem ders kitaplarında olduğu gibi "Cumhuriyet Çocuklarına Malûmât-ı Vataniye"de de vatanı analarımızı sevdiğimiz gibi sevmemiz gerektiği, vatanın yaşaması ve yükselmesi için gerekirse bu uğurda seve seve canımızı feda etmemiz gerektiği özellikle vurgulanmaktadır (Adil, 1926, s. 52). Hatta vatana karşı vazifenin tüm vazifelerden daha mukaddes olduğunu söyleyen yazar, yaşamakla vatan arasında doğrudan ilişki kurmaktadır. Vatan kavramının yanı sıra millet kavramının da açıklaması yapılarak öğrencilerin bilgi dağarcıkları kuvvetlendirilmeye çalışılmıştır. Millet kavramı, "bir toprakta yaşayan ve aynı kanuna aynı hakimiyete tabii olan insanların hayat-ı mecmuasıdır" denilerek açıklanmıştır (Adil, 1926, s. 53).

Millete karşı vazifelerimiz başlığı içinde anlatılan bir başka konu da kanuna itaat olmuştur. Yazar, insanlar arasında ilişkileri tayin etmek amacıyla hazırlanan kanunlara, toplumun her ferdinin uymak zorunda olduğunu söylemektedir (Adil, 1926, s. 55). Benzer şekilde askerliğinde her Türk erkeğine düşen bir vazife olduğunu söyleyen yazar, vakti geldiğinde askerlik vazifesinin büyük bir zevkle yerine getirilmesi gerektiğini hatırlatmaktadır (Adil, 1926, s. 56).

Hak ve vazife kategorisinin bir alt teması ise "Beşeriyete Karşı Vazifelerimiz" başlığını taşımakta ve konu da dört alt başlıkla eserde değerlendirilmektedir: Adalet, Hayata ve Namusa Hürmet, Fikir ve Vicdan Hür müdür ve Teavün. Yazar "Adalet" konusuyla, sadece yaşadığımız topluma, ailemize, dostlarımıza ya da muallimlerimize karşı vazifelerimizin olmadığını aynı zamanda dışımızdakilere karşı da görevlerimizin olduğunu vurgulamaktadır. Örneğin hayatımıza, malımıza, namusumuza başkalarının nasıl ki tecavüz etme hakkı yoksa, benzer şekilde bizim de başkalarının haklarına müdahale etme hakkımız bulunmamaktadır (Adil, 1926, s. 60). Eserde beşeriyete karşı vazifelerden ikincisi "hayata ve namusa hürmet" başlığını taşımaktadır. Bu konu başlığında ise insan için yaşamının büyük bir nimet olduğu ve diğer insanların hayatlarına hürmet etmenin ise vazife olduğu söylenmektedir (Adil, 1926, s. 62). Söz konusu kategorinin üçüncü teması ise "Fikir ve Vicdan Hür Müdür?" başlığını taşımakta ve yazar bu konuda eserinde şu sözlere yer vermektedir (Adil, 1926, s. 65):

Herkesin serbestçe düşünmesine ve düşündüğünü serbestçe ifade etmesine ve yazmasına fikir hürriyeti ve matbuat hürriyeti denir. Bu hürriyetlere hürmet etmek lazımdır. Bir memlekette fikir hürriyeti olmazsa orada en zeki inanlar bile hiçbir şey yapamazlar. Herkesin din ve itikadına da hürmet etmelidir. Herkesin dini kendi nazarında muhteremdir. Bir vakitler din namına pek çok cinayetler yapılmıştır, fakat bugün medeni insanlar herkesin dinine hürmet etmektedir.

Beşeriyete karşı son vazife olarak "teavün" konusuna yer verilmiştir. İnsanlığa karşı bir diğer vazife olarak muhtaç olanlara yardım etmek gösterilmektedir. Zenginlerin sadece kendilerini değil, fakir insanları da düşünmeleri gerektiğini söyleyen yazar, öte yandan, insanlara yardımın sadece para ile olmadığını, başkalarına fiziki ve manevi yardımın da belirleyici olduğunu eklemektedir (Adil, 1926, s. 67). 
"Toplumsal Uyum" kategorisi içinde hak ve vazifeler açıklandıktan sonra, "Hemşerilik Vazifesi" başlığı altında belediyenin neliği tartışılarak, "Belediyelerin Sıhhi Vazifeleri" adı altında bir başlık daha açılmıştır. Belediyeler konusu içinde öncelikle, aynı şehir ve kasabada oturan kimselere hemşeri dendiği ve hemşerilerin yaşadıkları şehirlere karşı vazifeleri olduğu, bu vazifeleri yapmak için içlerinden bazılarını seçerek bir idare teşkilatı kurdukları ve bu teşkilata "belediye" adı verildiği söylenmektedir (Adil, 1926, s. 69-70). Konu başlığının sonunda ise "Belediyelerin Sıhhi Vazifeleri" başlığıyla belediyelerin vazifeleri şöyle sıralanmaktadır: Lağımlar, Sokakların Temizlenmesi, Şehirde Temiz Su Tertibatı ve Çarşı, Pazarda Muzır Şeylerin Menni, Dükkân, Mağaza, Lokanta ve Otellerde Sıhhi Tedbirler, almak (Adil, 1926, s. 73-76):

Eserde "Toplumsal Uyum" kategorisinde gruplandırılan bir diğer konu da vatandaşların vazifeleri konusu olmuş, "Vatandaşlara Teveccüh Eden Vazifeler" başlı̆ı̆na yer verilerek konu noktalanmıştır. "Belediyelerin şehrin sıhhatine müteallik vazifelerine mukabil vatandaşlara teveccüh eden vazifeler" alt başlığında ise bu vazifelerin açıklamasına yer verilmiştir (Adil, 1926, s. 77). Konunun devamında "Evlerde Sıhhi Riayet" başlığıyla bir meskende bulunması gereken özellikler anlatılmaktadır (Adil, 1926, s. 77-78). Eserin devamında yaşanılan evlerin rutubetsiz ve güneş alıyor olmasının haricinde dikkat edilmesi gereken bir diğer husus da evlerimizde içtiğimiz suyun temiz ve berrak olması, bunun yanı sıra teneffüs ettiğimiz havanın temizliği olması gerektiği anlatılmıştır (Adil, 1926, s. 78). Bir devlette yaşayan vatandaşlar ne kadar sağlıklı olursa, devletin de o kadar sağlam temeller üzerine kurulacağına inanan yazar, çocuklara eserinin devamında spor yapmalarını ve yediklerine içtiklerine dikkat etmelerini öğütlemektedir.

"Toplumsal Uyum" kategorisi içinde incelediğimiz bir diğer başlık ise "Ev Dahilinde Sıhhi Temizlik" adını taşımaktadır. Söz konusu konuda bir önceki konu başığında anlatılanlara benzer şekilde sağlıklı bir topluma sahip olabilmek için herkesin öncelikle kendi evini temiz tutması, çöplerini kapalı kaplarda muhafaza etmesi, çöplerini belediye araçlarına vermesi hatırlatılmaktadır (Adil, 1926, s. 83-84). Öte yandan, evlerin temizliğine dikkat edilmediğinde sivrisineklerin çevremizi kaplayarak sıtma hastalığına sebep olabileceği de eserde söylenmektedir (Adil, 1926, s. 85). Eserde vatandaşlara teveccüh eden vazifelerden bir diğeri ise belediyelerin vazifelerini kolaylıkla yerine getirebilmesi için şehir halkının onlara yardım etmesidir. Belediyelerin halktan bekledikleri ise şunlardır (Adil, 1926, s. 87):

Mesela kolera veya dizanteri gibi bulaşıcı hastalıklar zuhurunda belediye gazetelerle halka bazı tembihlerde bulunur. Çürük meyve yenilmemesini, farelerin kapanlar vasıtasıyla tutulmasını, kaynatılmadan su içilmemesini tembih eder. İşte bu takdirde halk da belediyenin şu tembihlerine riayet etmelidir. Aksi halde bu hastalıklar şehirde kolayca tevsi eder. Herkesin hayatı tehlikeye girer. Kezalik yollarda ve araba, şimendifer, vapur, tramvay tünel gibi mahallerde yerlere tükürmemek de halkın riayet edeceği bir vazifedir. Çünkü tükürmek hastalıkların sirayetine sebep olur. Sokaklarda, tramvaylarda yerlere tükürmek sıhhate muzır oldukları başka, terbiyeye de mugayirdir. 
Benzer şekilde itfaiye teşkilatının da vazifelerini yerine kolaylıkla getirebilmeleri için şehir halkının dikkat etmesi gereken hususlar şöyle sıralanmıştır: "Mangalları açık bırakmamak, kibrit ve lamba ile oynamamak, lambaları hava cereyanları bulunan yerlere koymak, ocakları sık sık temizlettirmek, su borularının metin olmasına dikkat etmek, ağaçlı yerlerde ateş yakmamak, mangal sobalarına dikkat etmek riayet olunacak tedbirlerdendir" (Adil, 1926, s. 90). Öte yandan sokak ve caddelerin iyi bir halde muhafaza edilmesi için çocuklara düşen vazifeler ise şöyle sıralanmaktadır (Adil, 1926, s. 95):

Fena terbiye gören bazı kimseler yollara meyve kabuğu, kâğıt süprüntü gibi şeyler atarlar. Bu hal pek çirkindir. Sokak ve caddeleri kirletecek bozacak şeyleri yerlere atmamak duvarları tahrip etmemek ve caddelerdeki ağaçlara dokunmak evlerin önünü temiz tutmak sokak ve caddelerde oyun oynamak her medeni insanın vazifesidir. Evlatlarım iyi bir şehrin sakinleri olmak şehrinizi gerek kendi vatandaşlarınıza gerek ecnebilere beğendirmek sevdirmek isterseniz sokakları temiz tutmaya ve belediyenin yaptığı iyi şeyleri muhafaza etmeye çalışınız. Belediyeler çocuklar için şehirlerde oyun mahalleri yaparlar. Çocuklar sporlar ve idmanlar yaparlar ve oyun oynarlar. Sokaklarda oynamak terbiyeli bir çocuğun işi değildir.

Eserde toplumsal uyum kategorisi içinde incelediğimiz bir diğer konu ise "Fukara ve Muhtaçlara Yardım" başlığını taşımaktadır. Yazar, eserinde fakir ve muhtaç insanlara yardım etmenin vatandaşlık vazifeleri arasında olduğunu söylemektedir. Eserde, her memlekette sefaleti yok etmek için kurumların kurulduğu, İngiltere'de yardım edebilmek adına halktan fakirlik vergisi toplandığı ve benzer şekilde bizde de Darülacezeler için tiyatrolardan vergi alındığı söylenmektedir (Adil, 1926, s. 99). Eser son olarak "Vatandaşları Himaye" konu başlığıyla polislerin bir memleketteki asayişi temin etiği ve polislerin vazifelerini kolaylaştırmak için halkın da yardımcı olması gerektiği açıklamalar arasında yer almaktadır.

\section{Sonuç}

Cumhuriyet'in ilk yıllarından itibaren eğitim alanında köklü değişiklikler yapılmıştır. Yapılan değişiklikler ve hazırlanan öğretim programlarıyla temelde iyi ya da ahlaklı yurttaşlar yetiştirmek amaçlanarak pek çok ders kitabı yazılmıştır. Bu ders kitaplarından çoğunun dolaylı da olsa temel amacı yeni nesli, Cumhuriyet'in ilke ve inkılapları doğrultusunda ahlaklı yurttaşlar olarak yetiştirmektir. Öte yandan pek çok ders kitabının örtük amacı olan ahlaklı ve iyi yurttaş hedefi, 1924 ve 1926 ilk Mektepler Programlarının ve "Musabahat-ı Ahlakiye ve Medeniye" gibi derslerin doğrudan amacını oluşturmuştur.

Araştırmamızın temelini oluşturan "Cumhuriyet Çocuklarına Malûmât-ı Vataniye" adlı ders kitabı da sıraladığımız amaçlar doğrultusunda kaleme alınmıştır. Muslihiddin Adil tarafından kaleme alınan "Cumhuriyet Çocuklarına Malûmât-ı Vataniyye" 24 Ağustos 1926 tarihinde İstanbul Orhaniyye Matbaası'nda basılmıştır. İlk Mektepler dördüncü sınıf öğrencileri için hazırlanan eseri yazar, çocukları yaşadıkları çağa ayak uyduran, vatanın birlik ve beraberliğini her şeyin üstünde tutan, medeni yaşamı tanıyan bireyler olarak yetiştirebilmek için kaleme aldığını belirtmiştir. 
Cumhuriyet Çocuklarına Malûmât-ı Vataniye adlı eserde sabırlı, çalışkan, ahlaklı, toplumu tanıyan, hak ve vazifelerini bilen, ailesine, kardeşine, dostuna ve öğretmenlerine karşı sorumlu bireyler yetiştirmek amaçlanmıştır. Başka bir deyişle kitapta "Bireysel Gelişim" ve "Toplumsal uyum" başlıklarıyla kategorize ettiğimiz değerlerin, okul çağındaki öğrencilere kazandırılmaya çalışıldığını söyleyebiliriz. Eserde yer edinen konularla, güçlü bir devletin ancak sağlam aile, iyi yetişmiş ve ahlaklı bireylerle kurulabileceği sıklıkla vurgulanmaktadır. Bireyin zihinsel, ruhsal ve bedensel olarak sağlam ve sağlıklı olması da yine güçlü bir devletin vazgeçilmezleri arasında sayılmaktadır. Öte yandan "Cumhuriyet Çocuklarına Malumat-ı Vataniye" de vurgulanan devlet-aile ikilemi yeni kurulan devletin en büyük gücünün ulusdevlet yapısının yerleşmesiyle olanaklı olduğunu hatırlatır niteliktedir. $\mathrm{Bu}$ anlamda araştırmamızın temelini oluşturan "Cumhuriyet Çocuklarına Malûmât-ı Vataniye" adlı ders kitabı yazıldığı dönemin küçük bir örneği görünümündedir.

"Cumhuriyet Çocuklarına Malûmât-ı Vataniye"de, "Bireysel Gelişim" ve "Toplumsal Uyum" kategorilerinin frekans ve yüzde değerleri alındığında toplumsal uyum kategorisinin kelime ve sayfa sayısı bakımlarından bireysel gelişim kategorisinden daha fazla yer kapladığı sonucuna varılmıştır. Eserde, "Fert ve Cemiyet" konu başlığıyla da uzun uzun anlatıldığı gibi, yetiştirilmesi hedeflenen yeni nesilden bireysel gelişimi ya da ben bilincine sahip olması beklendiği gibi yaşadığı toplumu kendi canından üstün tutabilmek yani vatanın birlik ve devamı için canını feda edebilmesi de ön görülen değerler arasında gösterilmektedir. Örneğin eserde bireylerin sağlıklı olmasıyla devletin sağlam temeller üzerinde kurulması arasında doğrudan ilişki kurulmuştur.

Cumhuriyet'in ilk yıllarında kaleme alınan "Cumhuriyet Çocuklarına Malûmât-ı Vataniye"de konu başlıklarından ve bazı konuların sonuna eklenen "Hülasa ve Güzel Sözler" başıklarında verilen açıklamalardan da ahlaklı nesil yetiştirilmesinde okul, aile ve toplumun öneminin sıklıkla vurgulandığı anlaşımaktadır. Eserden hareketle ahlaklı bireylerin yetiştirilmesi noktasında dini öğelere doğrudan gönderme yapılmadı̆̆ı anlaşılmaktadır. Bunun yerine ahlaklı bireyin dindar ya da dindar bireyin ahlaklı olduğu çıkarımına yer verilmediği de eserden çıkarılabilecek sonuçlar arasında gösterilmektedir. Eser yazılma amacının dışına çıkmamıştır. Eserde temelde anlatılmak istenenler konular aracılığıyla ve nasihat yöntemi bir öğrenim yaklaşımı olarak kullanılarak anlatılmıştır.

Sonuç olarak, ahlak eğitiminin Türkiye'deki kökenleri üzerine yapılacak her türlü araştırmanın nitelikli bir birikim ortaya çıkartacağı belirgindir. Güçlü, nitelikli nesiller yetiştirmek isteyen devletin, modern dünya ile arzulanan birey arasındaki ilişkiyi kurgularken vatani öncelikleri merkeze taşıması dönem koşullarına uygun bir politika olup eğitim sisteminin öncelikli hedefi haline gelmiştir. İncelediğimiz eser, bu çerçevede ahlak eğitiminin Türkiye'de nasıl kurgulandığını örnekleyerek Cumhuriyet'in beklediği ideal vatandaşı gözler önüne sermektedir. 


\section{Kaynakça}

Adil, M. (1926). Cumhuriyet çocuklarına malûmât-ı vataniyye. İstanbul: Orhaniyye.

Akagündüz, S. Y. (2017). Ahlaklı yurttaş. İstanbul: Yeni İnsan.

Akagündüz, Ü. (2016). Cumhuriyet yılları eğitim tarihinde halka sağlık bilgisini sadeleştirerek anlatmaya çalışan bir eser: Sıhhi Konuşuk (1927). 4. Uluslararası Tarih Eğitimi Sempozyumu (1-3 Eylül) (s. 761-769). Muğla: Pegem.

Alabaş, R. (2018). Cumhuriyet'in ilk yıllarında ilk mekteplerde insani ve toplumsal değerler eğitimi: resimli, yeni musâbah'at-ı ahlâkiye ve medeniye ders kitabı örneği. Çağdaş Türkiye Tarihi Araştırmaları Dergisi, XVIII(36), s. 55-87.

Aslan, E. (2011). Türkiye Cumhuriyeti'nin ilkokullarda izlediği ilköğretim programı: 1924 ilk mektepler müfredat programı. ilköğretim Online, 10(2), s. 717-734.

Başgöz, ì. (2005). Türkiye'nin eğitim çıkmazı ve Atatürk. İstanbul: Pan.

Cicioğlu, H. (1982). Türkiye Cumhuriyet'inde ilk ve ortaöğretim. Ankara: DTCF.

Çayır, K. (2014). Biz kimiz? Ders kitaplarında kimlik, yurttaşlık, haklar. İstanbul: Tarih Vakfı.

Çelenk, S., Tertemiz, N. I. ve Kalaycı, N. (2000). Ilköğretim programları ve gelişmeler. (Yay. Haz. A. Tazebay.) Ankara: Nobel.

Ergün, M. (1982). Atatürk devri Türk eğitim tarihi. Ankara: DTCF.

Gergeon, F. (2006). Osmanlı-Türk modernleşmesi (1900-1930). (A. Berktay, Çev.) İstanbul: Yapı Kredi.

Maarif Vekaleti. (1340 (1924)). Ilk mekteplerin müfredat programı, ilk tedrisat dairesi. İstanbul: Matbaa-i Amire.

MEB. (2006). Milli Eğitim Şûraları (1921-2006). Ankara: Talim ve Terbiye Kuruluğu Başkanlığı.

Ozankaya, Ö. (1990). Türkiye'de laiklik. İstanbul: Cem.

Pingel, F. (2003). Ders kitaplarını araştırma ve düzeltme rehberi (UNESCO). (N. Elhüseyni, Çev.) İstanbul: Tarih Vakfı.

Timur, T. (2001). Türk devrimi ve sonrası. Ankara: İmge.

Türkiye Cumhuriyeti Maarif Vekaleti. (1927). Ilk mektepler müfredat programı. İstanbul: Devlet.

Türkiye Cumhuriyeti Maarif Vekaleti. (1930). Illk mektep müfredat programı. İstanbul: Devlet. Üstel, F. (2009). Makbul vatandaşın peşinde. İstanbul: İletişim.

Yıldırım, A. ve Şimşek, H. (2006). Sosyal bilimlerde nitel araştırma yöntemleri. Ankara: Seçkin. Zürcher, E. J. (2004). Modernleşen Türkiye'nin tarihi. (Y. S. Gönen, Çev.) İstanbul: İletişim. 


\section{Ekler}

Ek 1. Cumhuriyet Çocuklarına Malûmât-ı Vataniye Kapak Sayfası

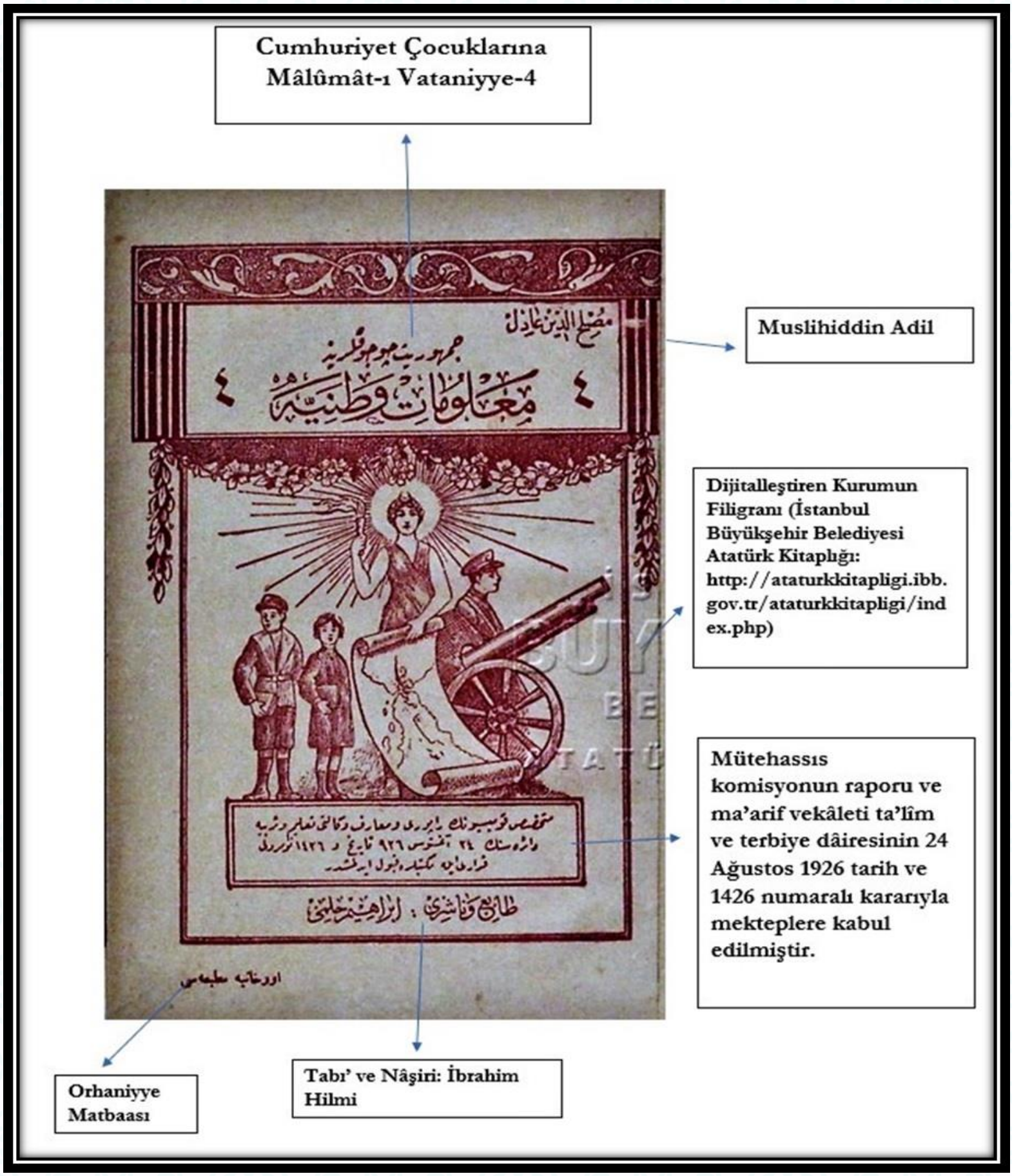


Ek 2. Cumhuriyet Çocuklarına Malûmât-ı Vataniye Kitabı İç Sayfalarından Örnek

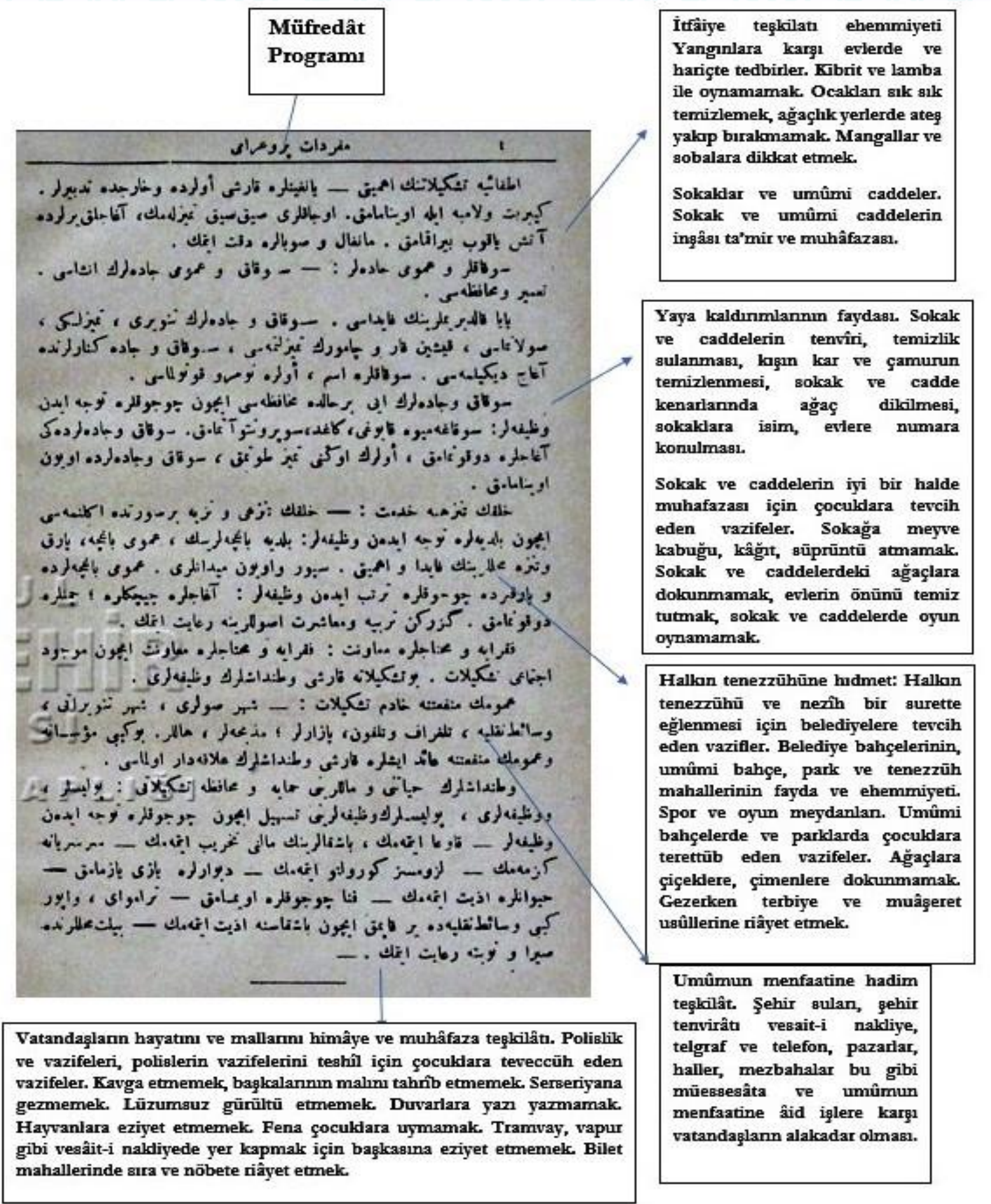

